\title{
ABCG1 wt Allele
}

National Cancer Institute

\section{Source}

National Cancer Institute. ABCG1 wt Allele. NCI Thesaurus. Code C113600.

Human ABCG1 wild-type allele is located in the vicinity of $21 \mathrm{q} 22.3$ and is approximately 98

$\mathrm{kb}$ in length. This allele, which encodes ATP-binding cassette sub-family G member 1

protein, plays a role in lipid homeostasis. Aberrant expression of the gene in

macrophages is associated with Tangier disease. 